\title{
早期体験学習としての救命講習並びに福祉体験学習の実施とその評価
}

\author{
酒井英二, 寺町ひとみ, 西田弘之, 足立哲夫*
}

\section{Evaluation of the Cardio Pulmonary Resuscitation/Automated External Defibrillator Class and Disability Experiences Class Provided as Part of the Early Exposure Program}

\author{
Eiji SAKAI, Hitomi TeramaCHI, Hiroyuki NishIDA, and Tetsuo ADACHI* \\ Gifu Pharmaceutical University, 5-6-1 Mitahora-higashi, Gifu City 502-8585, Japan
}

(Received March 14, 2008; Accepted May 14, 2008)

\begin{abstract}
To evaluate the cardio pulmonary resuscitation (CPR) /automated external defibrillator (AED) operation class and disability (wheelchair, inconvenience, and eye mask) experiences class provided as part of the 2007 early exposure program at Gifu Pharmaceutical University, a questionnaire survey was conducted among students who had participated in this program. Many students had already participated in a previous CPR class (79\%) and/or disability experiences class $(55 \%)$, and some students had even experienced a real-life situation requiring these techniques $(9 \%$ and $14 \%$, respectively). Those with previous training experience performed more effectively in this year's early exposure program than those without such an experience. Due to the active participation of most students during the training, a significantly higher level of satisfaction with the program than that previously expected was achieved (mean score on a 5-grade scale: 3.98 vs. 3.31 for the CPR/AED class; 4.35 vs. 3.69 for the disability experiences class). Furthermore, many students commented that their experience in this year's program increased their motivation for future training and confidence to cope with a real-life situation in the future. These findings demonstrated the effectiveness of repeated training in mastering the CPR/AED and welfare-related techniques, and the usefulness of incorporating such training into the early exposure program. To provide regularly a meaningful early exposure program, the concept of a "model core curriculum" led by learners as well as the age-mixing method with senior students supporting instruction of their juniors should be introduced.
\end{abstract}

Key words — early exposure program; disability experiences class; model core curriculum; cardio pulmonary resuscitation (CPR)/automated external defibrillator (AED) class; questionnaire survey

\section{緒言}

平成 18 年度から 6 年制薬学教育がスタートし, 「薬学教育モデル・コアカリキュラム」音に沿って, 多くの大学において, 1 年次に「早期体験学習」が 導入されている.この体験学習の目的は, 卒業生が 薬剤師として活躍する現場を入学後の早期に見学・ 体験することにより, 将来, 医療人としての活躍を 目指す薬学生の学習に対するモチベーションを高揚 することにある．岐阜薬科大学(以下，本学とする) においても,「薬学教育モデル・コアカリキュラム」 の早期体験学習の各到達目標の達成に向け, 初年度 の平成 18 年度には, 病院見学, 薬局見学, 製薬企

岐阜薬科大学

*e-mail: adachi@gifu-pu.ac.jp
業見学, 救命講習を導入し，また，見学実習の事 前・事後には small group discussion（SGD）にて 薬剂師の職能，見学施設についての調査，見学実習 後のまとめと成果の発表を行った。平成 19 年度に は，モデル・コアカリキュラムの早期体験学習「保 健, 福祉の重要性を具体的に体験する」という到達 目標に向けての学習の充実を目指し, 救命講習に加 えて福祉体験学習 (車いす体験, 不自由体験, アイ マスク体験）を導入した。早期体験学習の各項目の うち, 病院見学並びに薬局見学については, 従来の 4 年制教育の中での病院・薬局実務実習の経験を基 に実施され，その成果や課題と方策の提示もなされ ているが, ${ }^{2-4)}$ その他の早期体験学習の項目につい ては，大学ホームページでの公表はみられるもの の, 5) その詳細な実習評価は報告されていない。そ 
こで，本論文では，平成 19 年度早期体験学習の一 環として本学において実施した「救命講習」並びに 「福祉体験学習」の結果とこれに対する受講生の評 価について報告する.

\section{方法}

\section{1. 早期体験学習の実施要領平成 19 年度に} 入学した薬学科 (6 年制) 1 年生 83 名（男性 49 名, 女性 34 名)，薬科学科（4 年制） 1 年生 48 名（男性 33 名, 女性 15 名）の全員を対象に，以下のプログ ラムで早期体験学習を実施した。

科目名：「早期体験実習」，薬学科・必修，薬科学 科・必修, 1 年生通年科目

科目目標：薬学生としての学習に対するモチベーシ ヨンを高めるために，卒業生が活躍する現場などを 体験し，医療人としての自覚を高め，さらに将来の 目標を明確に認識する。

前期は，製薬企業見学（目標：製薬工程とそこに 係わる薬学部卒業生の業務を見聞する，180 分）, 病院見学（目標：病院における薬剂師の業務を見聞 する, 180 分), 講義 (90 分) を 3 回, SGD (90 分) を 3 回実施した。SGD の目標は，1 回目は「薬剤 師の職能についてグループで討議できる」，2回目 は製薬企業見学前に「製薬企業見学の目的，見学の ポイント，服装や態度について討議できる」, 3 回 目は病院見学前に「見学する病院について調べ，見 学目標，服装や態度について討議できる」.

後期は，薬局見学（目標：薬局における薬剤師の 業務を見聞する，90 分），SGD（90 分） 1 回「見学 で学んだことをグループで討議し，パワーポイント を使つて発表する」の実施とともに，下記に示す救 命講習並びに福祉体験学習を実施した。また，病院 見学実習の成果は,「岐阜薬科大学・薬学教育フォ一 ラム」にて各グループの代表がポスター発表を行 い, フォーラムに参加した本学教員, 他大学教員, 病院・薬局実習指導薬剤師と討議を行つた. ${ }^{6-8)}$

救命講習は，「医療人として一次救命処置の技能 を修得する」を目的とする学習であり，本学の体育 館内で， 1 年生 131 名を 10-12 名のグループに分 け，グループ毎に岐阜北消防署員の指導の下で心肺 蘇生法（CPR）並びに自動体外式除細動器（AED） 操作を体験した（180 分）。

福祉体験学習は，「身体的不自由を持つ人の気持
ちを理解し（車いす自己操作，不自由体験，アイマ スク体験），さらに理解した上で支援する技能を修 得する（車いす操作支援，視力不自由者支援）」を 目的とする学習であり, 本学の講義室, 学内階段や 廊下を利用し，131 名を 6 班に分け，岐阜市社会福 祉協議会職員並びにボランティア職員の指導の下で 実施した (90 分).

Figure 1 には救命講習並びに福祉体験学習の様子 を写真で示す

2. アンケート調査とデータの統計処理 救命 講習受講後に Fig. $2(\mathrm{~A})$, 福祉体験学習受講後に Fig. 2 (B) に示す用紙を用いてアンケート調査を実 施した。アンケート結果を基に，基礎データ表を作 成し，統計処理を行った２ 群間の回答の差（体験 学習経験の有無の差）の検定には $\chi^{2}$ 検定，対応の ある 2 群間のスコア平均值の差の検定には Wilcoxon 符点付順位和検定，対応のない 2 群間のスコア 平均值の差の検定には Mann-Whitney $U$ 検定を利 用し，いずれの検定法でも $p<0.05$ を有意水準した.

\section{結果}

1. アンケートの回収結果救命講習後のアン ケート調査では 131 名（男性 82 名，女性 49 名）全 員から回答を回収でき回収率 100\%であった。福祉 体験学習後のアンケート調査では 128 名（男性 79 名，女性 49 名）から回答を回収でき回収率 $98 \%$ で あった。

\section{2. 救命講習, 福祉体験学習の経験の有無}

Figure 3 (A) に示すように，過去に救命講習への 参加経験のある学生は 79\%（131 名中 103 名）で, この割合に男女間で差はなかった（ $\chi^{2}$ 検定， $p=$ 0.385 ）。受講時期（複数回答あり）は，小/中学校 15 名，高等学校 27 名，自動車学校 84 名，その他 1 名であり, $82 \%$ が自動車学校で受講していた。次に 今回の体験学習への参加姿勢との関連性を検証した 結果，過去に救命講習の受講の経験がある学生は, 今回の救命講習へのスムーズな参加度 [Fig. 2(A) の質問 5）のスコア平均值が 4.43 であり，受講経 験がない学生のスコア平均值 3.86 に比べ有意に高 值であることが判明した $(p<0.01$ by Mann-Whitney $U$ - 検定)。また，過去に受講経験がある学生の $61 \%$ ，そのときの経験が今回の体験学習に「大変 役立った」あるいは「役立った」 [Fig. 2(A)の質問 


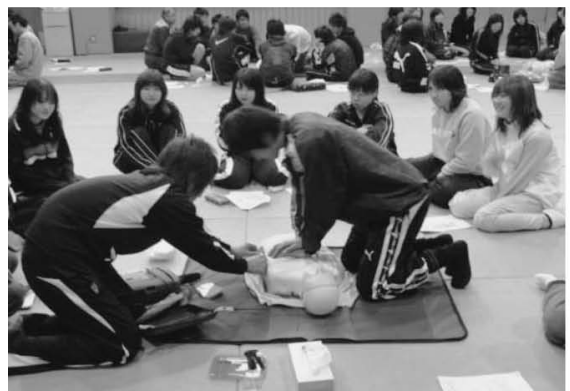

线命講習

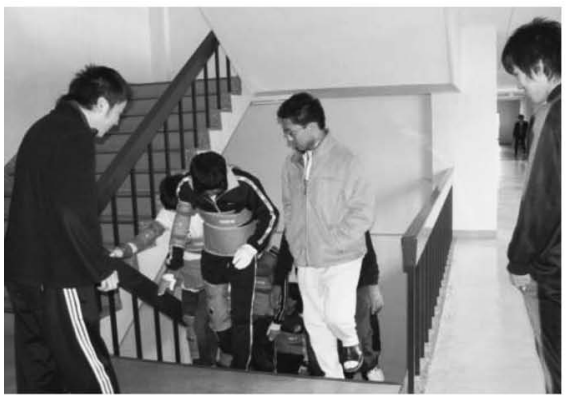

不自由体験

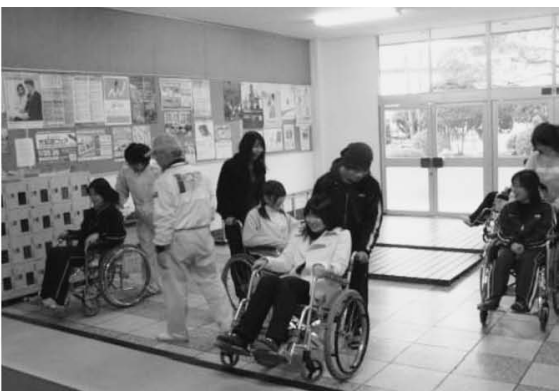

車イス体験

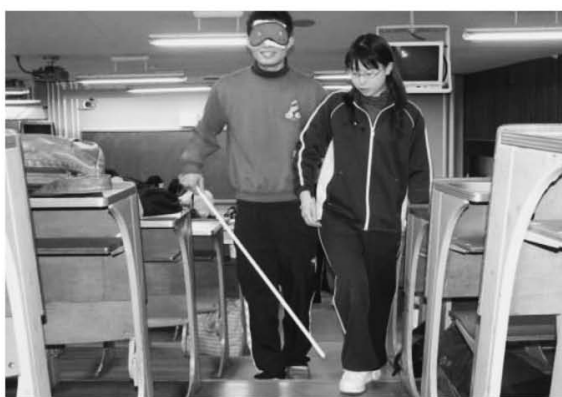

アイアスク体験

Fig. 1. Photographs of CPR/AED Class and Disability Experiences Class

(A)

学生用 早期体験実習(救急救命謮習) アンケート

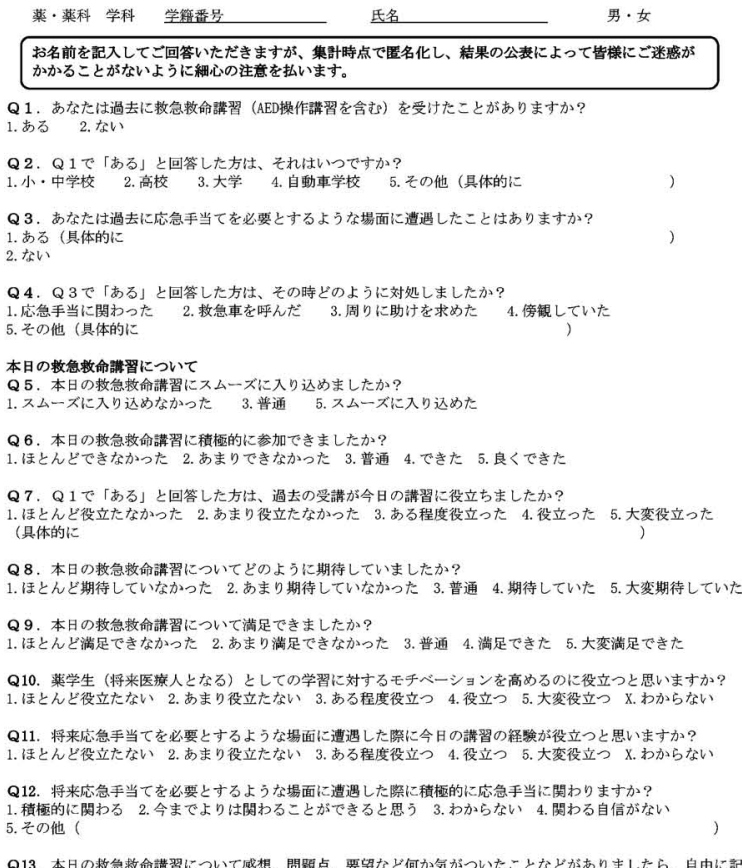

(B)

学生用 早期体験実習(福祉体験学習) アンケート

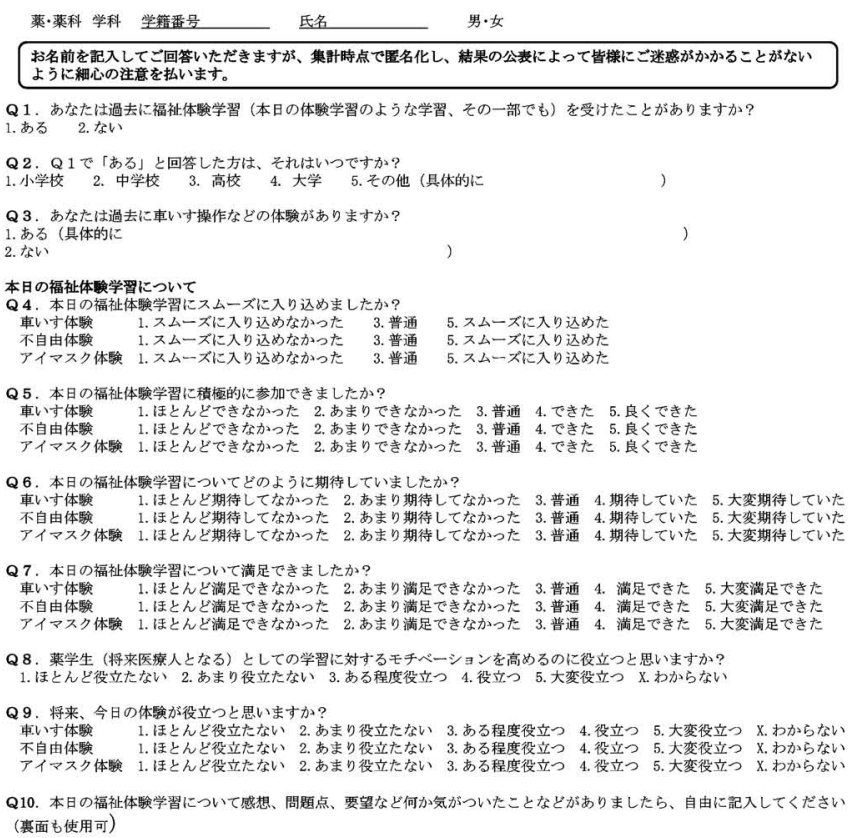

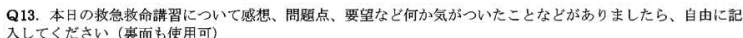

Fig. 2. Questionnaire Forms for the CPR/AED Class (A) and the Disability Experiences Class (B)

7]と回答した. 一方, 今回の救命講習への参加の 積極性 [Fig. 2(A)の質問 6］のスコア平均值は, 過去の受講経験がある学生は 4.23, 受講経験がな い学生は 4.03 であり，両者間に有意な差は認めら
れなかつた。

過去に福祉体験学習 (車いす体験学習) への参加 経験のある学生は 55\%（128 名中 71 名）であり, 女性（67\%）の方が男性（48\%）より高い傾向にあ 
(A) 救命講習の経験

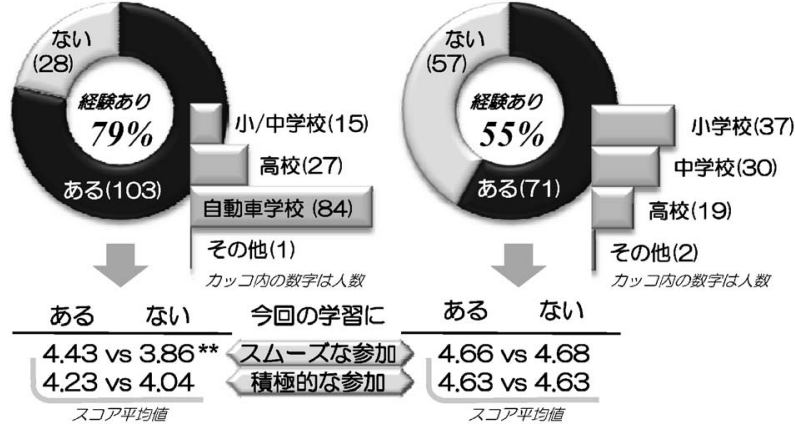

Fig. 3. The Effect of Previous Training Experience ${ }^{* *} p<0.01$ by Mann-Whitney $U$-test.

つたが，有意差はなかつた（ $\chi^{2}$ 検定， $p=0.051 ）$. 受講時期（複数回答あり）は, 小学校 37 名, 中学 校 30 名，高等学校 19 名，その他 2 名であった。 上 述の救命講習の場合と異なり, 今回の福祉体験学習 への参加姿勢（Fig. 2(B)の質問 4：スムーズな参 加，質問 $5:$ 積極的参加についてのスコア）に対 し，過去の受講経験の有無の影響は認められなかっ た [Fig. 3(B)].

3. 過去の実体験の有無 過去に応急手当を必 要とする場面に遭遇した経験がある学生は $9 \%$ （131 名中 12 名）で，そのときの対応についての回 答の内訳は，「応急手当にかかわつた」 3 名，「救急 車を呼んだ」 3 名,「周りに助けを求めた」 3 名, 「傍観していた」2 名，無回答 1 名であった.

過去に車いす操作などの実体験（体験学習やボラ ンティア学習などは除く）のある学生は $14 \% （ 128$ 名中 18 名）であり，そのときの状況の内訳は，自 分自身の怪我等 10 名，家族・友人等の怪我や介護 8 名であつた。この車いす操作の実体験を持つ学生 は全員が今回の福祉体験学習（車いす体験）に対し スムーズに参加することができ，スコア平均值 5.00 は，実体験のない学生のスコア平均值 4.60 に 比べ有意に高值であった（ $p<0.05$ by Mann-Whitney $U$ - 検定)

\section{4. 体験学習への参加姿勢「体験学習にス} ムーズに入り込めましたか?」の問いに対し，Fig. 4 (A) に示すように, 回答のスコア平均值が救命講 習では 4.31, 福祉体験学習では 4.57 であり，いず れの体験学習でも多くの学生がスムーズに参加でき たことが判明したが，福祉体験学習の方がスコア平 均值が有意に高く，よりスムーズに参加できたこと
(A) 早期体験学習へのスムーズな参加

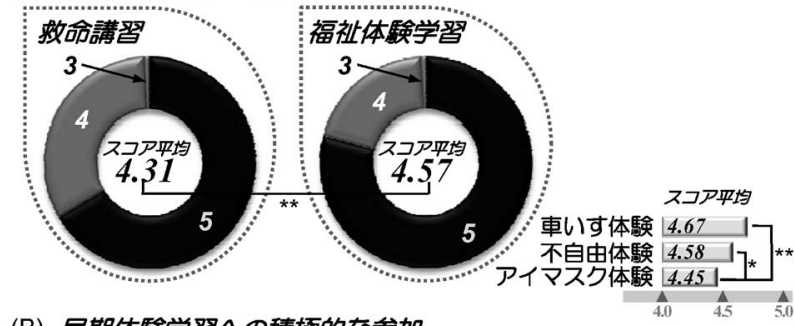

(B) 早期体駼学習への積極的な参加

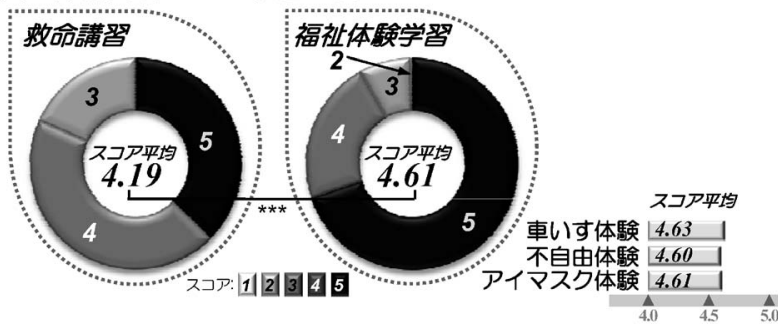

Fig. 4. Attitudes toward Participation in the Early Exposure Program (Smooth/Active Participation)

${ }^{*} p<0.05,{ }^{* *} p<0.01,{ }^{* * *} p<0.001$ by Wilcoxon signed-ranks test.

が示された $(p<0.01$ by Wilcoxon 符点付順位和検 定)。また，3種類の福祉体験学習項目の中ではア イマスク体験（スコア平均値 4.45）が他の 2 項目 よりスムーズに入り込むことが若干難しい状況であ つたが $(p<0.01 \mathrm{vs}$ 車いす体験及び $p<0.05$ vs 不自 由体験 by Wilcoxon 符点付順位和検定)，これは， 他の体験より恐怖感が強いためであると思われる （受講生の自由記述より）。

次に「体験学習に積極的に参加できましたか?」 の問いに対し，Fig. 4(B)に示すように，回答のス コア平均值が救命講習では 4.19 , 福祉体験学習で は 4.61 であり，いずれの体験学習でも多くの学生 が積極的に参加したことが示されたが，福祉体験学 習のスコア平均值が有意に高值であった $(p<0.001$ by Wilcoxon 符点付順位和検定).

5. 体験学習への期待度と満足度 Figure 5 に 示すように, 救命講習後の満足度スコア平均值 （3.98）は学習前の期待度（3.31） と比較し有意に 高值であった（ $p<0.001$ by Wilcoxon 符点付順位 和検定)。また，福祉体験学習においても 3 種の体 験項目全体で学習前の期待度のスコア平均值 (3.69) より学習後の満足度（4.35）が有意に高值であり, 各項目別でも車イス体験 $(3.65 \rightarrow 4.38)$, 不自由体 験 $(3.69 \rightarrow 4.27)$ ，アイマスク体験 $(3.73 \rightarrow 4.41)$ の いずれも学習後の満足度が有意に高值であった（ $p$ $<0.001$ by Wilcoxon 符点付順位和検定). 


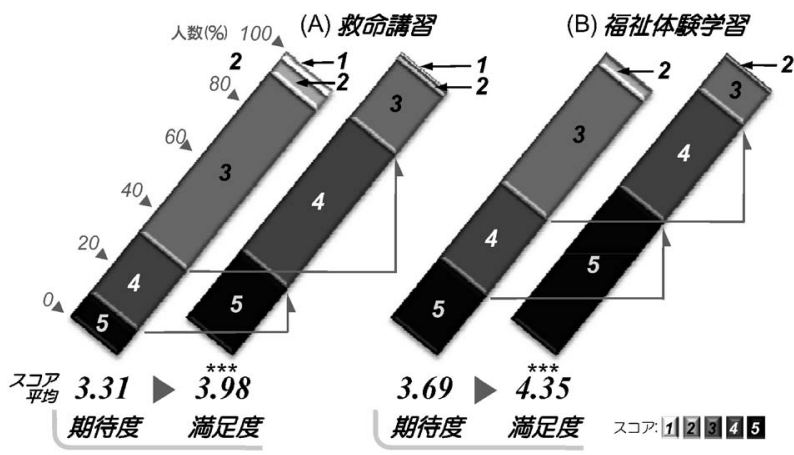

Fig. 5. Students' Prior Expectations and Actual Level of Satisfaction Concerning the Early Exposure Program ${ }^{* * *} p<0.001$ by Wilcoxon signed-ranks test.

\section{6. モチベーションの高揚と将来の有用性}

「薬学生（将来医療人となる）としての学習に対 するモチベーションを高めるのに役立ったと思いま すか?」の質問に対し, 救命講習及び福祉体験学習 のそれぞれのスコア平均值が 3.37，3.54 であっ た。一方，「将来，本日の体験が役立つと思います か?」の質問に対し, 救命講習及び福祉体験学習の それぞれのスコア平均值が $4.11 ４ .09$ であり, 救 命講習, 福祉体験学習ともに「学習に対するモチ ベーションの高揚」に対してより，「将来必要とな る場面に遭遇した場合の対処」に役立つとの考えが 有意に高かった $(p<0.001$ by Wilcoxon 符点付順 位和検定）（Fig. 6)。救命手技の習得の結果，将 来，必要となるような場面に遭遇した場合，「積極 的に関わる」との回答 $26 \%$ ，「今までよりは関わる ことができると思う」63\%は，「わからない」9\%， 「関わる自信がない」 $2 \%$ に比べ格段に多く，今回の 救命講習の将来への有用性が明らかになつた.

\section{考察}

6 年制薬学教育の中での早期体験学習として, 病 院見学，保険薬局見学，製薬企業見学に加え，「薬 学教育モデル・コアカリキュラム」の早期体験学習 の到達目標「保健・福祉の重要性を具体的な体験に 基づいて発表する」に対応した介護・福祉施設見学 実習9) や不自由体験・救命講習が実施されている. ${ }^{5)}$ また，「薬」を身近に感じさせるための学内での調 剂学入門実習10)や KJ 法を用いた $\mathrm{SGD}^{11)}$ を導入し ている大学もある。病院・薬局での早期体験学習 は，長年の病院・薬局実務実習（旧課程 4 年生での 実習) での実績を踏まえ，また，その実習内容や評

\section{(A) モチベーションの高揚}

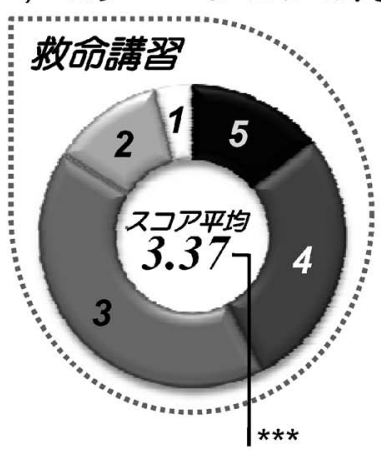

(B) 将来の有用性

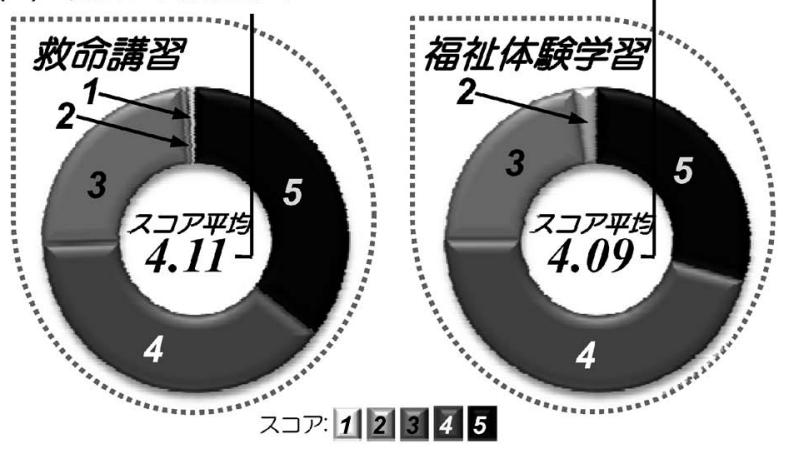

Fig. 6. The Benefits of the Early Exposure Program to Increase Students' Motivation and Their Confidence to Cope with Future Situations

${ }^{* * *} p<0.001$ by Wilcoxon signed-ranks test.

価法に関しての報告や提言 ${ }^{12-14)}$ を参考にして計画・ 実施され，その成果についても既に報告されてい る. ${ }^{2-4)}$ 本学においても, 平成 18 年度, 19 年度の病 院での早期体験学習の成果を各グループ代表が本学 主催の「岐阜薬科大学・薬学教育フォーラム」にお いてポスター発表し, ${ }^{6-8)}$ それとともに，病院・薬 局，製薬企業での見学学習の際に学生を対象として 行つたアンケート調査の結果についても報告してい る. 6,7) しかし, 病院・薬局での早期体験学習に比 べ, それ以外での学習については, 救命講習やハン デ体験の医療系学部合同早期体験学習についての大 学ホームページでの公表, ${ }^{5}$ 不自由体験実習を高学 年の医療薬学系実習の中に取り入れた報告 ${ }^{15)}$ がある が詳細な実習評価は報告されていない。本論文で は, 平成 19 年度に本学で早期体験学習の一環とし て実施した救命講習並びに福祉体験学習の際に受講 生を対象に行ったアンケート調査の結果をまとめた.

本学においては，「早期体験実習」は薬学科，薬 科学科とも必修科目である。本科目は，「(6 年制) 薬学教育モデル・コアカリキュラム」の早期体験学 
習に則つて実施している科目であるが，将来，研究 者や技術者としての活躍を目指す 4 年制薬科学科の 学生にとっても，自身が開発に携わる医薬品の実際 の使用者である患者，身体的弱者の辛さや要望を知 り，病院・薬局という医療現場を見聞することが, 薬学生としての自覚を高め, 将来の目標を決める上 で重要であり，どのような職種に就いても早期体験 学習の経験を活かす機会があるとの判断から必修科 目としている.

救命講習・福祉体験学習と病院，薬局，製薬企業 を訪問する早期体験学習との違いは，一般的には，

1）後者は見学主体の学習であるのに対し，前者は 体験型学習であること，2）ほとんどの学生は病院 薬剂部 (薬局), 保険薬局調剂室, 製薬工場を初め て見学するのに対し, 救命講習・福祉体験学習につ いては，かなりの学生が経験しているという点にあ り，アンケートへの回答についても，これらの点が 背景にあると考えられる.

救命講習については 79\%の学生が既に受講経験 があると回答し，しかもその多くの学生が自動車学 校で受講しているため, 今回の体験学習までの期間 が比較的短いものの，手技の再確認・定着につなが ったようである（自由記述から）。また，過去の救 命講習で心肺蘇生法を体験した学生でも AED 操作 の体験学習は初めての学生が多い。近年，多くの公 共施設に AED が設置されているが，使用法につい ての体験学習が追いついていないと懸念される。車 いす操作に比較しても救命処置の手技は, 講習会等 での体験の有無が，実際に必要になった際の介入や 次回の講習会等へスムーズな参加に大きく影響して いることが判明し（Fig. 3)，また，受講後は多く の学生が「将来役立つ」（Fig. 6)，あるいは，「そ のような場面に遭遇した際に今までより積極的に介 入できそうだ」と回答している，学外の消防署職員 の指導の下で体験学習を行ったことが満足度の向上 につながつたようであるが（自由記述から），学生 1 人の体験に要する時間が長いため, 効率的な体験 学習を継続的に実施するためには，実施要領の再検 討，学内指導者の養成等が課題になると考えられる。

車いす体験も $55 \%$ の学生が既に学習している が，多くが小/中学校の総合学習での体験であるた め，今回とは学習内容が異なり（アイマスク体験は 初めての学生が多い)，本体験学習で「身体的弱者
の日常動作が予想以上に大変であることを改めて体 感した」という回答が多かった（自由記述から）。 福祉体験学習は多くのボランティア職員のきめ細か い指導の下で行ったこともあって，90\%以上の学生 が積極的に参加し，「この体験が将来役立つ」と回 答している. 今回は，学舎内での体験学習であった が，実施方法を調整すれば，戸外での実施を含める ことが可能になる（自由記述で戸外での実施要望あ り).

Figure 5 に示すように, 救命講習, 福祉体験学習 のいずれも学習前の期待度に比べ，学習後の満足度 が有意に高值であったが，このような期待度に対す る満足度の上昇は, 病院見学実習（平成 18 年度 $3.96 \rightarrow 4.04$, 平成 19 年度 $4.41 \rightarrow 4.11)$ や薬局見学 実習（平成 18 年度 $3.84 \rightarrow 3.96$, 平成 19 年度 3.88 ４.11）に比べて大きな值であった。この理由とし ては，1）病院・薬局見学実習については，多くの 学生が初めての経験であり，見学前の期待度がもと もと非常に高くスコアが上がる余地が少ないこと，

2）病院・薬局見学実習が見学主体の学習であるの に対し，救命講習や福祉体験学習は直に体験する学 習であるため高い満足度が得られ易いことによると 思われる. 真野ら9) も早期体験学習の中の病院見学 では期待度から満足度が $4.2 \rightarrow 4.3$, 薬局見学が 4.1 $\rightarrow 4.4$ と報告しており, 上記の本学での病院・薬局 見学実習とほぼ同程度あった。また，彼らは同じ論 文のなかで早期体験学習のなかの実習発表会は期待 度 3.2 から満足度 4.0 に大きく上昇したことを報告 しているが, 9) 本学においても，上述の「岐阜薬科 大学・薬学教育フォーラム」で早期体験学習の成果 をポスター発表した学生を対象としたアンケート調 査の結果，発表を行ったことにより満足度が大変高 まったという回答を得ており，見学主体の実習のみ に比べ，体験型，成果報告型実習では高い満足度が 得られることが再確認された。

早期体験学習の実施には病院・薬局実務実習と同 様に，地域の実習受け入れ施設の協力が不可欠であ る. 特に平成 22 年度からは病院と薬局でのそれぞ れ 2.5 力月の長期実務実習が開始され，実務実習受 け入れを依頼している施設に，加えて早期体験学習 を依頼することが多くなるため，多くの実習受け入 れ施設で早期体験学習の必要性が理解されていると はいえ, 3) 現場の日常業務への支障をなるべく軽減 
する方策が必要である。近年，大学院生を実習や演 習での教育補助に充てるティーチングアシスタント （TA）制度が確立されつつあり，TA の導入に対し ては「きめ細かい指導が受けられる」，「質問し易 い」,「大学院進学へのモチベーション高揚につなが る」など教育を受ける側の学生の評価も高い。ま た，「薬学教育モデル・コアカリキュラム」は，本 来，指導者が「何をどこまで教えなければならない か」を示すものではなく，学習者が「何をどこまで 学ぶか」を示したものであることを考慮すれば，病 院や薬局で長期実務実習を履修中の学生（高学年の 学生）が，場合によっては，その日程や施設の状況 に合わせ，早期体験学習に訪れた 1 年生の指導を分 担することや一緒に SGD を行うことが可能ではな いかと考える. さらに，学内で行う福祉体験学習に おいても，既に受講経験のある学生が低学年の学生 の指導補助に当たるなどエイジミキシング学習を導 入することは, 受講生と指導学生双方にとって有益 で，効率よい早期体験学習の実施につながると考え る.

謝辞 救命講習でご指導頂いた岐阜北消防署職 員の方々，福祉体験学習でご指導頂いた岐阜市社会 福祉協議会職員並びにボランティア職員の方々に深 謝いたします。また，アンケート結果の集計にご協 力いただいた岐阜薬科大学グリーンファーマシー教 育推進センター職員の方々に感謝の意を表します.

\section{REFERENCES}

1) The Pharmaceutical Society of Japan, Model Core Curriculum for Pharmacy Education: 〈http://www.pharm.or.jp/rijikai/curriculum/ index.html $>$

2) Takayama A., Ohnishi N., Hashizume T., Tsushima M., Yasuda E., Kanazawa H., Shibakawa M., Kuroda K., Yokoyama T., Jpn. J. Pharm. Health Care Sci., 33, 680-686 (2007)

3) Hasegawa Y., Hasuike K., Ezaki K., Nakao
N., Hirata C., Shibata K., Kim K., Nishida H., Azuma K., Hirai M., Tokuyama S., Fukushima S., Yamaoka Y., Iwakawa S., Matsuyama K., Uchida T., Jpn. J. Pharm. Health Care Sci., 34, 64-72 (2008).

4) Hirata C., Nakao N., Shibata K., Yamamoto T., Sawasaki T., Hasegawa Y., Hasuike K., Nishida H., Azuma K., Kim K., Tokuyama S., Fukushima S., Yamaoka Y., Iwakawa S., Hirai M., Matsuyama K., Uchida T., Jpn. J. Pharm. Health Care Sci., 34, 204-213 (2008).

5) 〈http : //www10.showa-u.ac.jp/ pharm/gp1. html $>$

6) "1st Forum for Pharmaceutical Education in Gifu Pharmaceutical University”, 2007.

7) "2nd Forum for Pharmaceutical Education in Gifu Pharmaceutical University”, 2007.

8) 〈http://www.gifu-pu.ac.jp/educate/educate03. html $>$

9) Mano Y., Noguchi T., Yamada H., Hara A., Takeda H., Iga T., Jpn. J. Pharm. Health Care Sci., 33, 702-709 (2007).

10) Nishimura A., Naruhashi K., Kokufu M., Morita K., Shibata N., Jpn. J. Pharm. Health Care Sci., 33, 634-644 (2007).

11) Takayanagi R., Yamada Y., Ozeki T., Yokoyama H., Hiratsuka A., Ohno N., Sasatsu M., Yakugaku Zasshi, 126, 1179-1183 (2006) .

12) Teramachi H., Takashima E., Kubota M., Tsuchiya T., Jpn. J. Pharm. Health Care Sci., 32, 997-1008 (2006).

13) Sagara H., Kitamura Y., Nawa H., Okazaki H., Sendo T., Gomita Y., Jpn. J. Pharm. Health Care Sci., 33, 331-338 (2007).

14) Teramachi H., Nakamura M., Takashima E., Kubota M., Adachi T., Tsuchiya T., Jpn. J. Pharm. Health Care Sci., 34, 374-389 (2008).

15) Hirai Y., Ueda K., Iwakawa S., Tomita H., Nagamine S., Kato F., Teraoka R., Otsuka M., Matsuda Y., Yagi K., Hirai M., Kiguchi T., Jpn. J. Pharm. Health Care Sci., 32, 346352 (2006). 